Georgia State University

ScholarWorks @ Georgia State University

Computer Information Systems Faculty

Publications

Department of Computer Information Systems

2011

\title{
Constructing an Index for Brand Equity: A Hospital Example
}

\author{
Yu-Che Wang \\ Chung Hua University, jerrywang@chu.edu.tw
}

Kuei-Chu Hsu

Sheng-Hsun Hsu

Chung Hua University, spolo@chu.edu.tw

J.J. Po-An Hsieh

Georgia State University, jjhsieh@gsu.edu

Follow this and additional works at: https://scholarworks.gsu.edu/cis_facpub

Part of the Management Information Systems Commons

\section{Recommended Citation}

Wang, Yu-Che; Hsu, Kuei-Chu; Hsu, Sheng-Hsun; and Hsieh, J.J. Po-An, "Constructing an Index for Brand Equity: A Hospital Example" (2011). Computer Information Systems Faculty Publications. 29.

https://scholarworks.gsu.edu/cis_facpub/29

This Article is brought to you for free and open access by the Department of Computer Information Systems at ScholarWorks @ Georgia State University. It has been accepted for inclusion in Computer Information Systems Faculty Publications by an authorized administrator of ScholarWorks @ Georgia State University. For more information, please contact scholarworks@gsu.edu. 


\title{
Constructing an index for brand equity: A hospital example
}

\author{
Abstract \\ If two hospitals are providing identical services in all respects, except for the \\ brand name, why are customers willing to pay more for one hospital than the other? \\ That is, the brand name is not just a name, but a name that contains value (brand \\ equity). Brand equity is the value that the brand name endows to the product, such \\ that consumers are willing to pay a premium price for products with the particular \\ brand name. Accordingly, a company needs to manage its brand carefully so that its \\ brand equity does not depreciate. Although measuring brand equity is important, \\ managers have no brand equity index that is psychometrically robust and \\ parsimonious enough for practice. Indeed, index construction is quite different from \\ conventional scale development. Moreover, researchers might still be unaware of the \\ potential appropriateness of formative indicators for operationalizing particular \\ constructs. Toward this end, drawing on the brand equity literature and following the \\ index construction procedure, this study creates a brand equity index for a hospital. \\ The results reveal a parsimonious five-indicator brand equity index that can \\ adequately capture the full domain of brand equity. This study also illustrates the \\ differences between index construction and scale development.
}

Keywords: Brand equity, brand equity index, index construction, scale development

\section{Introduction}

Brand development itself is not a new idea, but branding is becoming 
increasingly important for service and product providers because consumers now have access to a great deal information and a wider choice of products and services than ever before. To differentiate its offerings from others, a company must build a strong brand image in customers' mind, as a successful brand can add value to a product (i.e., brand equity). Aaker (1991) proposes that brand equity can create value for the firm as well as for the customer. From the customers' perspective, they can use brand to speed the purchasing process and to decrease purchasing risks, because a familiar brand can be perceived to be reliable and of reasonable quality (Aaker, 1991).

Customers can also get additional emotional value from branding attributes (e.g., social status). From the firm's point of view, strong brand equity can increase company revenue, generate higher customer loyalty and decrease vulnerability to competitive marketing campaigns (Keller, 1993). Cobb-Walgren, Beal, and Donthu (1995) show that a high level of brand equity can lead to high consumer preferences and purchase intentions.

Brand equity is the incremental utility with which a brand endows a product (Yoo, Donthu \& Lee, 2000). Positive brand equity occurs when the consumer is familiar with the brand and holds some favourable, strong, and unique brand associations in memory (Keller, 1993). If consumers perceive a particular brand favourably, they are more likely to choose, and pay a premium price for, products 
associated with that particular brand name. This outcome can produce tremendous competitive advantages for any firm.

Hence, companies need to know and measure the brand perceptions of their brands in customers' minds. While measuring brand equity is important, managers have few metrics that are psychometric robust and parsimonious enough to manage (Yoo \& Donthu, 2001). Thus, to develop a robust and parsimonious index for measuring brand equity is useful.

Index construction is quite different from conventional scale development. The paradigm of scale development has been well-established (e.g., Churchill, 1979). However, Diamantopoulos \& Winklhofer (2001) suggest that researchers ignore an alternative approach that can be used to derive an index. Diamantopoulos, Riefler and Roth (2008, p. 1204) further contend that 'a substantial number of researchers engaging in measure development might still be unaware of the potential appropriateness of formative indicators for operationalizing particular constructs.' Indeed, index construction requires different considerations. As a result, researchers might hesitate to specify formative measurement models (Diamantopoulos, Riefler \& Roth, 2008). Simply put, an index is a composite latent variable (LV) and its calculation requires the use of formative rather than reflective indicators. When a LV is formatively measured, indicators cause the LV (see Figure 1). A typical example of 
formative indicators is socioeconomic status (SES), which includes education, income and occupation. Notice that these indicators (education, income and occupation) determine a person's SES rather than the reverse. For instance, if any one of these indicators increases, SES would increase. However, if a person's SES increases, such a change does necessarily infer a concomitant increase in all formative indicators. This property is particular for formative indicators.

In contrast, when considering a reflectively measured LV, the LV causes the indicators. A typical example of a reflectively measured LV is customer loyalty. Measures of customer loyalty usually include a customer's inclination to recommend a store to others and a customer's intention to shop at a particular store again. When a person's loyalty towards a store increases, he/she is more likely to recommend the store to others and to shop at the same store again. Thus, any change in a reflectively measured LV can cause an accompanying change in all its corresponding indicators concomitantly. Reflective indicators are essentially interchangeable, which is not true for formative indicators.

The primary objective of this study is to follow the index construction procedure that Diamantopoulos and Winklhofer (2001) and Arnett, Laverie, and Meiers (2003) suggest to develop a credible and parsimonious brand equity index. 
Figure 1 about here.

This study constructs a brand equity index for a hospital which can enable administrators and clinicians to understand and measure the level of the brand equity. This outcome can be beneficial for both patients and hospitals. This study surveys 250 patients in a hospital. Brand equity index is built by using Partial Least Squares (PLS). PLS is a structural equation modelling technique that is well suited to highly complex predictive models (Wold, 1985). PLS has several strengths that fit this study, including its ability to handle both reflective and formative LVs and the limited sample size. Diamantopoulos and Winklhofer's (2001, p. 274) call for researchers to use PLS (rather than covariance-based tools like LISREL) for constructing an index has also motivated us to take the PLS route.

The organisation of this study is as follows. The second section introduces the idea of brand equity. The third section elaborates the procedure for constructing an index. The fourth section demonstrates how to derive samples and explains the process of constructing an index. The final section concludes with a discussion.

\section{Brand equity}

While no common agreement exists with regard to how to measure brand equity (Yoo \& Donthu 2001), some efforts that can lead to consensus are recognized. First of 
all, most research in this area is based on Aaker (1991) and Keller (1993)'s

categorization of brand equity. Aaker (1991) suggest that brand equity has five

dimensions: brand loyalty, brand awareness, perceived quality, brand associations and

other proprietary brand assets. Arnett et al. (2003) suggest that brand equity is a

multi-dimensional construct, including name awareness, retailer association, service

quality, and store loyalty. Yoo and Donthu (2001) use confirmatory factor analysis

(CFA) to examine brand equity and show that brand equity is a three-dimensional

construct, combining brand awareness and brand associations into one dimension. On

the other hand, Pappu, Quester, and Cooksey (2005) believe that brand equity consists

of four dimensions: brand loyalty, brand awareness, perceived quality of brand, and

brand associations. This study follows the line of authors who suggest that brand

equity might at least include brand loyalty, brand awareness, perceived quality, and

brand associations. Although Yoo and Donthu (2001) show that brand equity is a

three-dimensional construct (brand awareness and brand associations are combined

into one construct), this study submits that brand awareness and brand associations

are two distinct constructs. Brand awareness refers to the likelihood that a brand name

will come to one's mind, whereas brand associations refer to a consumer's

interpretation of a brand. Brand associations are a much richer concept than brand

awareness. The four dimensions that are relevant to brand equity are elaborated 
below.

Brand awareness

Brand awareness is the likelihood that a brand name will come to a customer's mind when s/he is presented with a product category (Keller, 1993). A firm would be advantaged if consumers can think of its brand when considering purchasing a product in that category. That is, brand awareness provides the basis for trial and repeat purchase. Researchers state that brand awareness has a major impact on consumer choice (Hoyer \& Brown, 1990; Nedungadi, 1990). However, awareness alone may not lead to purchase; awareness may only result in curiosity about the product. Thus, brand awareness is a first and necessary, but not sufficient condition that leads to purchase.

Perceived quality

Brand awareness can create the basis for brand name recognition. But brand awareness does not necessarily result in consumer bonding with the brand. Brand bonding occurs after customers experience superb quality delivered by the company. Thus, brands are not only built by awareness, but also by quality of the product. Zeithaml (1988) defines perceived quality as the consumer's subjective judgment about a product's overall quality. Perceived quality encompasses all phases of a customer's interactions with a company, including all cues and encounters that occur 
before, during and after the transactions. Thus, perceived quality includes the

combination of all customer experiences.

\section{Brand associations}

In the beginning a brand may be just a name, symbol or design. But when customers begin to experience the products, they start forming positive or negative associations towards the products and the brands. Aaker (1991, p. 109) defines brand associations as 'anything linked in memory to a brand.' That is, brand associations refer to consumers' associations and interpretation of the brand, which includes functional (e.g., consumers might associate the Volvo car with robustness or safety) and emotional brand associations (e.g., consumers might associate the Lexus car with prestige or exclusivity). If consumers believe the brand can satisfy their needs, they form a positive association with the brand. These customers are more likely to make positive inference and accept any information conveyed through the brand. Hence, the company can even use this advantage to launch new products and attain quicker adoption rates of new products. As a result, when having positive associations in the minds of customers, a brand can add value to products. In contrast, if a consumer believes a brand is unfriendly, s/he forms a negative association.

\section{Customer loyalty}

Every successful brand represents a set of loyal customers. Aaker (1996) suggest 
that customer loyalty is a core dimension of brand equity. Customer loyalty has been defined as a 'deeply held commitment to rebuy or repatronize a preferred product/service consistently in the future' (Oliver, 1999). Loyal consumers respond more favourably to a brand than non-loyal consumers do. Although loyal customers may not necessarily purchase the product again, they may give out positive word-of-mouth reviews. A loyal customer base represents an entry barrier (from competition) and a basis for price premium (Aaker, 1996). Thus, increase in customer loyalty tends to enhance brand equity (Yoo et al., 2000).

\section{Procedure for index construction}

The procedure to develop an index builds from the work of Diamantopoulos and Winklhofer (2001) and Arnett et al. (2003). Figure 2 outlines the procedure.

Figure 2 about here

\section{Content specification and indicator specification}

The first step in index construction is to specify the scope of an index - the content that an index is intended to capture. After that, researchers have to specify the indicators that make up the index. Including comprehensive indicators is more important in a formatively measured LV than a reflectively measured LV. In formative 
relations, failure to consider all indicators of a LV will lead to incomplete definition of the LV. Bollen and Lennox (1991) suggest that omitting an indicator in a LV is omitting a part of the LV. For example, SES includes education, income and occupation. If a researcher mistakenly drop an indicator (e.g., education), the researcher may be at the risk of failing to comprehensively operationalise the construct. In case of reflective relations, indicators are usually interchangeable and the removal of an indicator does not necessarily change the essence of the underlying LV.

\section{Indicator collinearity}

As a formative measurement model is fundamentally based on multiple regression (Diamantopoulos \& Winklhofer, 2001), researchers have to examine the issue of multi-collinearity between formative indicators. Excessive collinearity among formative indicators can often lead to biased estimation of an indicator's effect on its corresponding LV, making researchers difficult to distinguish the influence of each indicator on a LV. To the contrary, for reflective measurement, multi-collinearity is less of an issue because reflective constructs involve only simple regression (Diamantopoulos \& Winklhofer, 2001).

\section{Indicator reliability}

Examining loadings is one way to assess item reliabilities. However, in the case of formative indicators, high loadings are not necessarily true because all indicators 
can be independent of one another. In the SES example, if one loses his/her job, this outcome does not imply that s/he loses her/his educational record. Thus, high loadings are not necessarily true; and reliability assessments, such as Cronbach's alpha, are not applicable. Under this situation Chin (1998) suggests that the weight of each indicator can be used to assess how much the indicator contributes to the LV. The weights of a formative construct's indicators in PLS are similar to the beta coefficients in a regression model. The magnitudes of weights can be interpreted as reliability of the indicators (Chin, 1998). Diamontopolous and Winklhofer (2001) suggested that if any of the item weightings for formative measures are non-significant, removing such non-significant indicators one at a time would be appropriate, until all paths are significant and a good fit is obtained.

\section{External validity}

The very nature of formative measurement renders an internal consistency method inapplicable. Bagozzi (1994, p. 333) states, 'The best we can do ... is to examine how well the index relates to measures of other variables.' As a result, assessment of external validity is crucial for index development. Two possible ways to measure the external validity of an index might include (1) using multiple indicators and multiple causes (MIMIC) model, and (2) examining how well the proposed index relates to other associated external constructs. In MIMIC model, the construct of 
interest is measured both formatively and reflectively (Arnett et al. 2001).

External validity and indicator inspection

The final investigation is to ensure that the remaining indicators could capture the full domain of brand equity. This step is necessary because, as Diamantopoulos and Winklhofer (2001) point out, indicator elimination carries the risk of changing the meaning of the construct. In the SES example, if one does not measure occupation in SES, this outcome may lead to under-specification of the construct. Therefore, indicator elimination should not depend only on statistical results; conceptual consideration is also important.

\section{Method}

Research site and data collection

Hospitals in developed economies are shifting from viewing patients as uneducated and with little choice to recognizing that consumers are educated, have many service demands, and are in the position of having more choice. This attitudinal shifting is taking place in Taiwan's health care industry also. Patients are now able to obtain information regarding hospitals' or doctors' performance through the Internet. Consequently, measuring brand equity of a hospital can enable the management to better understand their respective brand equity levels. This outcome is beneficial for 
both patients and hospitals.

This study surveyed patients at the $\mathrm{X}$ hospital in Taiwan. To encourage patients to answer the questionnaire, we gave small gifts to those who answered the questionnaire. We hired trained personnel to randomly distribute questionnaires at the entrance of $\mathrm{X}$ hospital in different time domains (i.e., morning, afternoon, and night time) for fourteen days. These trained personnel also assist elderly patients who may have difficulty in reading and answering the questionnaire. 250 patients answered the questionnaire. Average age of the respondents was 41 years; $39 \%$ were men and $61 \%$ were women.

\section{Index development process}

Following the procedure outlined in Figure 2, this study first specifies the scope of the brand equity and develops the measurement items. Brand equity consists of four dimensions: brand awareness, brand associations, perceived quality and customer loyalty. As stated earlier, to include comprehensive indicators is very important in constructing an index. Accordingly, indicators of brand equity must capture representative dimensions of brand awareness, brand associations, service quality and brand loyalty. 


\section{Step 1: Indicator specification}

A survey was designed to formulate the brand equity index. Whenever possible,

previously tested questions were used. Brand awareness is measured using scales adapted from Yoo et al. (2000). Brand awareness was measured by four items: (1) I am aware of $\mathrm{X}$ (the focal brand), (2) I can recognize $\mathrm{X}$ among other competing brands, (3) Some characteristics of X come to my mind quickly, and (4) I have difficulty in imagining $X$ in my mind (reverse-coded).

Two types of brand associations are product-related attributes and non-product-related attributes (Keller, 1993). Product-related attributes are defined as ingredients necessary for performing the product or service function sought by consumers. In the context of hospitals, product-related attributes refer to performance of the treatment. Product-related attributes of brand associations were measured by two items: (1) the treatment at $\mathrm{X}$ is useful, (2) when I have medical problems, $\mathrm{X}$ can treat them.

Non-product-related attributes are the external aspects of the product or service that relate to the purchase. Accordingly, the price of the service and the hospital image were considered as non-product-related attributes (Aaker, 1996; Keller, 1993); these factors represent considerations in the purchase process but typically do not relate directly to product performance. Two items used to measure the price of the service 
were adapted from Arnett et al (2003): (1) prices at X are acceptable and (2) service at $\mathrm{X}$ is good value for money. Hospital image was measured using scales adapted from Aaker (1996): (1) hospital X has a good image and (2) Hospital X is devoted to public welfare.

Service quality was measured using a scale adapted from Yoo et al. (2000).

Service quality was measured by three items: (1) the overall service level of $\mathrm{X}$ is high, (2) the likelihood that $X$ is reliable is very high, and (3) the service that $X$ provides meets my personal needs.

Customer loyalty was measured using a scale adapted from Yoo et al. (2000) and Arnett et al (2003). Customer loyalty was measured by three items: (1) when choosing medical care, $\mathrm{X}$ would be my first choice, (2) I would not consider other hospitals when $\mathrm{X}$ is capable of providing the medical care, and (3) even when medical care is available at other hospitals, I tend to go to X.

\section{Step 2: Indicator Collinearity}

Multicollinearity occurs when an independent variable correlates highly with a set of other independent variables. To assess multicollinearity, one can use variance inflation factor $(\mathrm{VIF})$ or tolerance $(\mathrm{VIF}=1 /$ tolerance) $($ Hair, Anderson, Tatham $\&$ Black, 1998). To calculate tolerance value, each independent variable becomes a dependent variable and is regressed against the remaining independent variables; 
tolerance is the amount of variance not explained in the regression $\left(1-R^{2}\right)$. Thus, a small tolerance (or high VIF) value denotes high collinearity (Hair et al., 1998, p. 193). As a rule of thumb, if VIF statistic is higher than 10, a problem of multicollinearity is indicated (Hair et al. 1998). However, with formative measures, multicollinearity poses a more serious problem (Peter, Straub \& Rai, 2007). Accordingly, Diamantopoulos and Siguaw (2006) suggest that if the VIF statistic for a formative measure is greater than 3.3, researchers can consider not to include such indicator in the construct. Because formative measurement models are based on multiple regressions, the intercorrelation among indicators affect their results. As a result, indicators with VIF value above 3.3 were dropped one at a time. This analysis is done by using SPSS, and several indicators were excluded (see Table 1).

Table 1 about here

\section{Step 3: Item reliability}

In terms of item reliability, this study employs PLS (PLS-Graph version 3.00 developed by Chin (2001)). A formative indicator can be dropped if its weight is non-significant (Diamontopolous \& Winklhofer 2001) and/or the indicator has high standard error relative to its weight (Diamantopoulos 2006). Non-significant 
indicators were dropped in an iterative process that deletes one indicator at a time, starting with the lowest t-value. As a result, indicator Aw4 was deleted because of its non-significant weight $(\mathrm{t}$-value $=0.11)$ and high standard error relative to its weight (standard error is 0.040 , weight is -0.004 ). Indicator Aw1 was also deleted because of non-significant weight $(\mathrm{t}$-value $=0.48)$ and high standard error relative to its weight (standard error is 0.072 , weight is 0.035 ).

\section{Step 4. External validity}

For examining external validity, the study uses MIMIC (see Figure 3). In MIMIC, the construct of interest (brand equity) is measured both formatively and reflectively. Indicators derived from previous analysis were used as formative indicators for the brand equity index. Three additional indicators that were previously used by Yoo and Donthu (2001) were used as reflective indicators for brand equity. These indicators include (1) it makes sense to go to $\mathrm{X}$, even if other hospitals provide the same service, (2) even if another hospital can provide the same service, I would prefer to go to X and (3) if another hospital is not different from X, it seems smarter to go to X.

Figure 3 about here

PLS was also used to measure the MIMIC model. Table 2 shows the result. The 
brand equity index explained a large portion of variance in the reflectively measured brand equity $\left(R^{2}=0.68\right)$. Considering the fact that only five indicators were used in the brand equity index, the amount of variance is considered adequate.

Whether or this simpler index model can still work as good as a full-indicator model is an issue. To address this issue this study uses full indicators to construct the brand equity index and test the MIMIC model. The $R^{2}$ value of the full-indicator MIMIC model is 0.75 . A comparison of the full-indicator model against the five-indicator model showed a relatively small deterioration in fit $\left(\triangle R^{2}=0.07\right)$. This outcome reveals that the five-indicator model can still sufficiently capture the content of the brand equity index. The path coefficient from the brand equity index to the reflectively measured brand equity is 0.82 with $p$ value less than 0.001 . This outcome also confirms that the index can sufficiently cover the construct of brand equity.

Table 2 about here

To further assess external validity, this study used another construct (customer loyalty) to examine whether brand equity index can predict customer loyalty. A high level of brand equity can result in a high level of customer loyalty. Items previously used by Hsu et al. (2006) were adapted for measuring customer loyalty. The two 
indicators are (1) I will go to $\mathrm{X}$ in the future and (2) I will recommend others to go to $\mathrm{X}$. The model is depicted in Figure 4, where brand equity index is the antecedent of customer loyalty. Table 3 shows the result of the measurement. The $R^{2}$ value of customer loyalty is 0.63 and the path coefficient from brand equity index to customer loyalty is 0.79 with $p$ value less than 0.001 , adding support to the external validity.

Step 4. Indicator inspection

The final investigation was to ensure that the remaining indicators could capture the full domain of brand equity. This step is necessary because as Diamantopoulos and Winklhofer (2001) point out, indicator elimination carries the risk of changing the meaning of the construct and hence indicator elimination should not depend only on statistical results; conceptual consideration is also important. After inspection, the remaining five indicators still could cover all 4 sub-dimensions of the brand equity index, with at least one indicator for each sub-dimension. Thus, the remaining indicators sufficiently capture the content of the brand equity index. 


\section{Conclusions}

If two hospitals are providing identical services in all respects, except for the brand name, why are customers willing to pay more for one hospital than the other? In the beginning brand names may be seen only as names or symbols, but after customers start to experience the products, the brand will incorporate customer experience, and expectations vis-à-vis a company's promises. Thus, the brand name is a name that contains value (brand equity), rather than just a name. Brand equity is the value endowed by the brand name to the product, such that consumers are willing to pay a premium price for products with the particular brand name. A company needs to manage its brand carefully so that its brand equity does not depreciate. Although measuring brand equity is important, managers have few metrics that are psychometric robust and parsimonious enough to manage (Yoo \& Donthu, 2001). This study follows Diamantopoulos and Winklhofer (2001) and Arnett et al. (2003) to construct a brand equity index for a hospital. Such an index provides a summary judgment on whether the brand is successful at creating the value propositions that customers desire.

The study constructs a brand equity index for a hospital, which is theoretically and statistically sound and parsimonious enough to manage. The results show how the construction of an index is different from scale development. Scale development 
places emphasis on intercorrelations among the indicators. High intercorrelations among indicators are desirable in scale development because high intercorrelations suggest high internal consistency among measurement items. In contrast to scale development, in index construction, indicators are retained as long as they have a distinct influence on the LV (Bollen, 1989). If intercorrelations among indicators are high, this outcome will lead to multicollinearity problems. High levels of multicollinearity in a formative measure are undesirable because the influence of each on the LV cannot be adequately determined. The final result shows that a brand equity index with five indicators is parsimonious enough to manage. The index consists of indicators of such constructs as brand awareness, brand associations, perceived quality, and customer loyalty. The results of the tests suggest that the five-indicator index can adequately capture the full domain of brand equity. Note that since the index is constructed in the context of a hospital, the five indicators developed for the hospital may not necessarily represent an optimum set in all contexts.

\section{Acknowledgements}

The authors acknowledge the support of the departmental research fund (G-U468) of the Hong Kong Polytechnic University and the research fund (CHU-97-M-002) of the Chung-Hua University.

\section{References}

Aaker, D.A. (1991). Managing brand equity. New York: The Free Press. 
Aaker, D.A. (1996). Measuring brand equity across products and markets. California Management Review, 38(3), 102-120.

Arnett, D.B., Laverie, D.A., \& Meiers, A. (2003). Developing parsimonious retailer equity indexes using partial least squares analysis: A method and application. Journal of Retailing, 79, 161-170.

Bagozzi, R.P. (1994). Structural equation models in marketing research: Basic principles. In R.P. Bagozzi (Ed.), Principles of marketing research. (pp. 317-385). Oxford: Blackwell.

Bollen, K., \& Lennox, R. (1991). Conventional wisdom on measurement: A structural equation perspective. Psychological Bulletin, 110(2), 305-314.

Bollen, K.A. (1989). Structural equations with latent variables. New York: John Wiley and Sons.

Chin, W.W. (1998). Issues and opinion on structural equation modelling. MIS Quarterly, 22(1), 7-16.

Chin, W.W. (2001). PLS-Graph User's Guide Version 3.0.

Churchill, G.A. (1979). A paradigm for developing better measures of marketing constructs. Journal of Marketing, XVI, 64-73.

Cobb-Walgren, C.J., Beal, C., \& Donthu, N. (1995). Brand equity, brand preferences, and purchase intent. Journal of Advertising, 24(3), 25-40. 
Diamantopoulos, A., Riefler, P., \& Roth, K.P. (2008). Advancing formative measurement models. Journal of Business Research, 61, 1203-1218.

Diamantopoulos, A., \& Winklhofer, H.M. (2001). Index construction with formative indicators: An alternative to scale development. Journal of Marketing Research, $38(2), 269-277$.

Hair, J.F., Anderson, R.E., Tatham, R.L., \& Black, W.C. (1998). Multivariate data analysis. New Jersey: Prentice-Hall.

Hoyer, W.D., \& Brown, S.P. (1990). Effects of brand awareness on choice for a common, repeat-purchase product. Journal of Consumer Research, 17(2), $141-148$

Hsu, S-H., Chen, W-H., \& Hsueh, J-T. (2006). Application of customer satisfaction study to derive customer knowledge. TQM and Business Excellence, 17(4), 439-454.

Keller, K.L. (1993). Conceptualizing, measuring, and managing customer-based brand equity. Journal of Marketing, 57(1), 1-22.

Nedungadi, P. (1990). Recall and consumer consideration sets: Influencing choice without altering brand evaluation. Journal of Consumer Research, 17, 263-276.

Oliver, R.L. (1999). Whence consumer loyalty. Journal of Marketing, 63, 33-44.

Pappu, R., Quester, P.G., \& Cooksey, R.W. (2005). Consumer-based brand equity: 
improving the measurement - empirical evidence. Journal of Product and Brand Management, 14(3), 143-154.

Peter, S., Straub, D., \& Rai, A. (2007). Specifying formative constructs in information systems research. MIS Quarterly, 31(4), 623-656.

Wold, H. (1985). Partial least squares. In S. Kotz \& N. Johnson (Eds.), Encyclopedia of statistical sciences. (pp. 581-591). New York: Wiley.

Yoo, B., \& Donthu, N. (2001). Developing and validating a multidimensional consumer-based brand equity scale. Journal of Business Research, 52(1), 1-14.

Yoo, B., Donthu, N., \& Lee, S. (2000). An examination of selected marketing mix elements and brand equity. Journal of the Academy of Marketing Science, 28(2), $195-211$.

Zeithaml, V.A. (1988). Consumer perceptions of price, quality, and value: A means-end model and synthesis of evidence. Journal of Marketing, 52, 2-22. 
Figure 1. A model with both formatively and reflectively measured latent variables

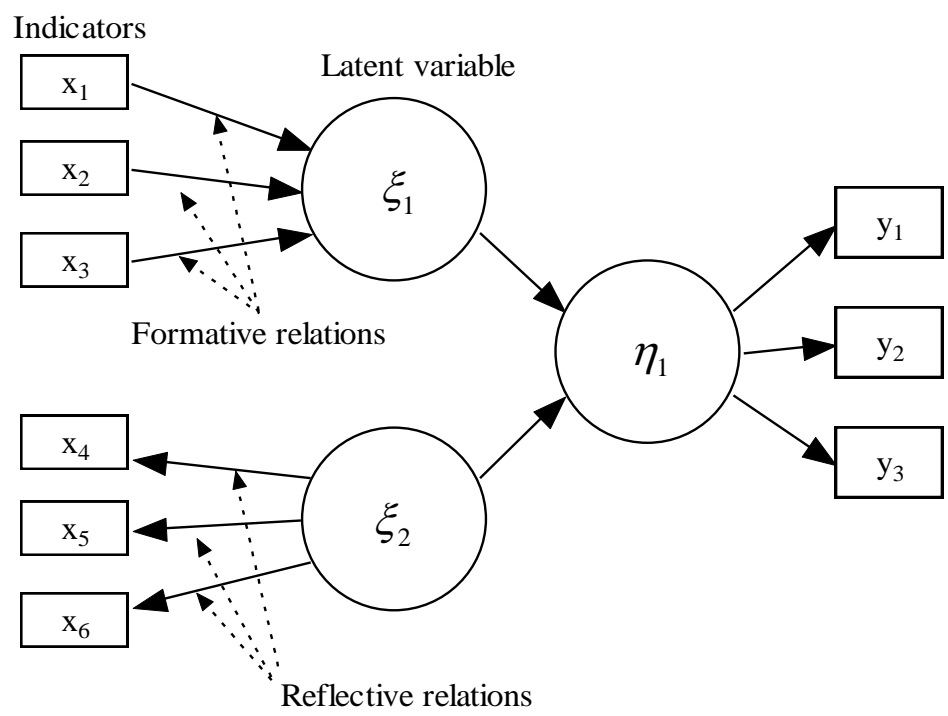


Figure 2. Procedure for index construction

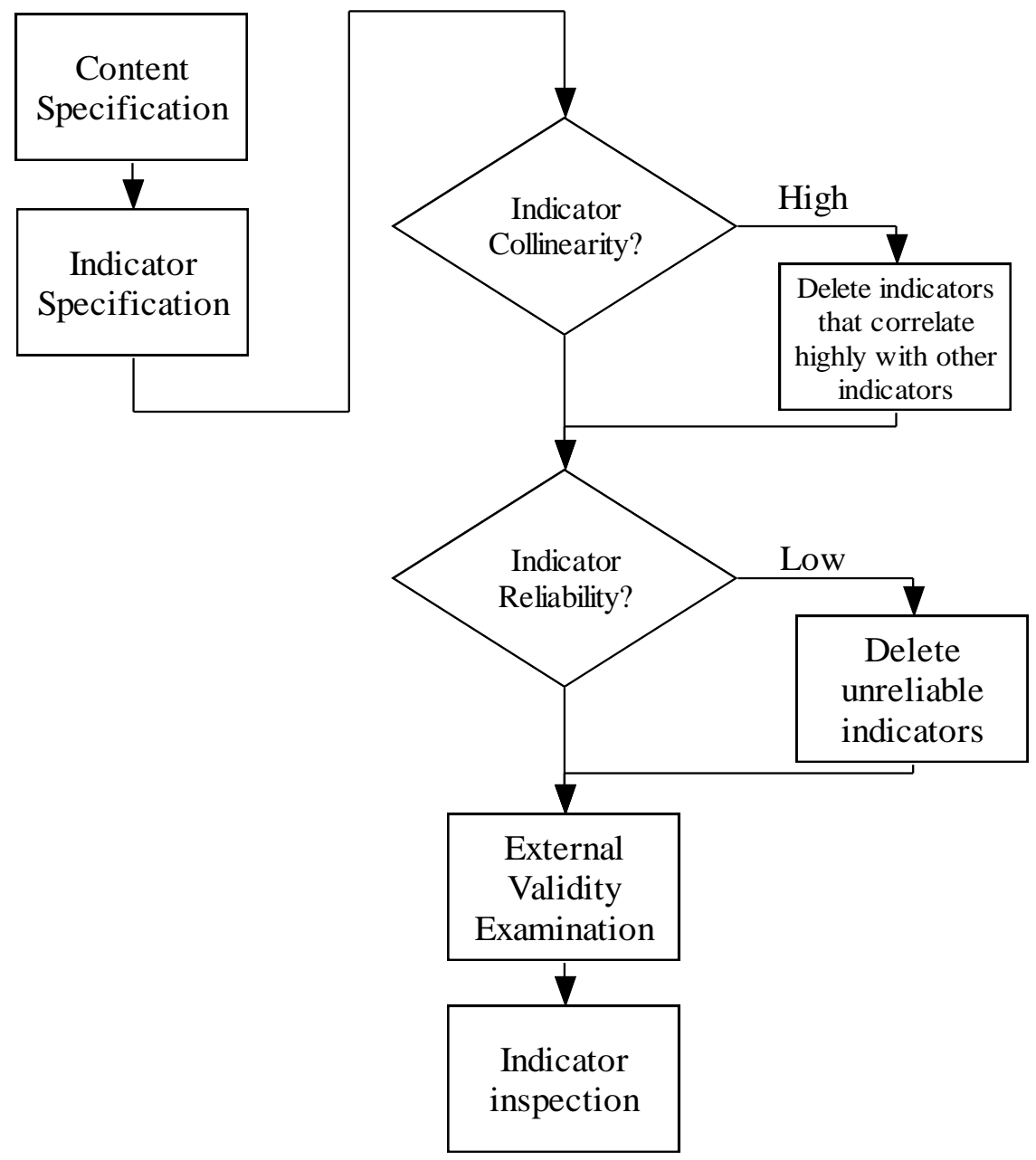


Figure 3. MIMIC model

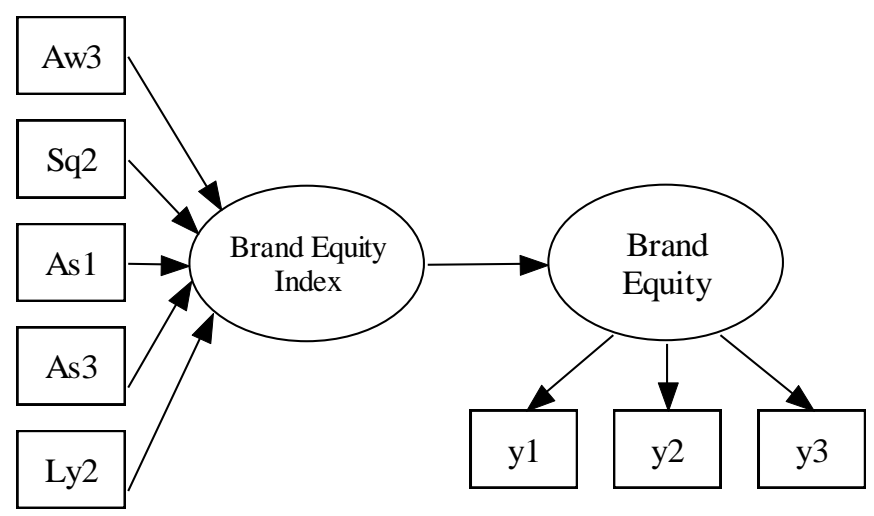


Figure 4. A model for external validity testing

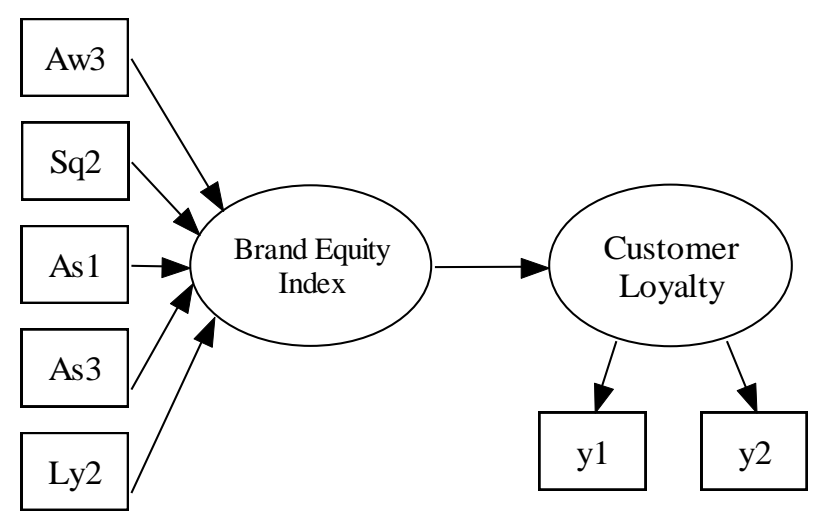


Table 1. Indicator collinearity

\begin{tabular}{|c|c|c|}
\hline Item & & VIF \\
\hline Aw1 & I am aware of $X$ & 2.44 \\
\hline $\mathrm{Aw} 2^{\mathrm{a}}$ & I can recognize $\mathrm{X}$ among other competing brands & 3.57 \\
\hline Aw3 & Some characteristics of $\mathrm{X}$ come to my mind quickly & 2.38 \\
\hline Aw4 & I have difficulty in imagining $X$ in my mind & 1.09 \\
\hline As1 & Treatment at $\mathrm{X}$ is useful & 2.38 \\
\hline As $2^{a}$ & When I have medical problems, $\mathrm{X}$ can treat them & 5.88 \\
\hline As3 & Prices at $X$ are acceptable & 1.72 \\
\hline As $4^{\mathrm{a}}$ & Service at $\mathrm{X}$ is a good value for money & 3.57 \\
\hline As $5^{\mathrm{a}}$ & Hospital X has a good image & 4.00 \\
\hline As6 ${ }^{\mathrm{a}}$ & Hospital $\mathrm{X}$ is devoted to public welfare & 4.17 \\
\hline $\mathrm{Sq} 1^{\mathrm{a}}$ & The overall service level of $X$ is high & 4.17 \\
\hline $\mathrm{Sq} 2$ & The likelihood that $\mathrm{X}$ is reliable is very high & 2.63 \\
\hline $\mathrm{Sq} 3^{\mathrm{a}}$ & The service that $X$ provides meets my personal needs & 5.56 \\
\hline Ly $1^{\text {a }}$ & When having medical care, $\mathrm{X}$ would be my first choice & 3.57 \\
\hline \multirow[t]{2}{*}{ Ly2 } & I would not consider other hospitals when $\mathrm{X}$ is capable of & 2.86 \\
\hline & providing medical care & \\
\hline $\mathrm{Ly}^{\mathrm{a}}$ & Even when medical care is available at other hospitals, I tend & 4.35 \\
\hline
\end{tabular}


to go to $\mathrm{X}$

a. Indicators that were dropped 
Table 2. PLS results

Brand equity index

\begin{tabular}{c|c}
\hline Formative indicators & Weights $^{\mathrm{a}}$ \\
\hline Aw3 $\rightarrow$ brand equity index & 0.21 \\
Sq2 $\rightarrow$ brand equity index & 0.35 \\
As1 $\rightarrow$ brand equity index & 0.24 \\
As3 $\rightarrow$ brand equity index & 0.18 \\
Ly2 $\rightarrow$ brand equity index & 0.28 \\
\hline
\end{tabular}

Brand equity

\begin{tabular}{c|c}
\hline Reflective indicators, internal consistency $=0.95$ & Loadings \\
\hline Brand equity $\rightarrow$ Y1 & 0.93
\end{tabular}

Brand equity $\rightarrow \mathrm{Y} 2$

0.93

Structural path, $R^{2}=0.68$

Path

Brand equity index $\rightarrow$ reflectively measured brand equity

0.82

a. In the case of formative measures, because high loadings are not necessarily true. Chin (1998) suggests use of weight of each item to assess how much it contributes to the LV. Weights of indicators of the formative construct in PLS are similar to the beta coefficients in a regression model. 
Table 3. PLS results

Brand equity index

\begin{tabular}{c|c}
\hline Formative indicators & Weights $^{\mathrm{a}}$ \\
\hline Aw3 $\rightarrow$ brand equity index & 0.25 \\
Sq2 $\rightarrow$ brand equity index & 0.29 \\
As1 $\rightarrow$ brand equity index & 0.30 \\
As3 $\rightarrow$ brand equity index & 0.22 \\
Ly2 $\rightarrow$ brand equity index & 0.22 \\
\hline
\end{tabular}

Customer loyalty

\begin{tabular}{l|c}
\hline Reflective indicators, internal consistency $=0.95$ & Loadings \\
\hline Customer loyalty $\rightarrow$ Y1 & 0.96 \\
Customer loyalty $\rightarrow$ Y2 & 0.96 \\
\hline Structural path, $R^{2}=0.63$ & Path \\
\hline Brand equity index $\rightarrow$ Customer loyalty & 0.79 \\
\hline
\end{tabular}

